\title{
Diminishing print vs. rising electronic publishing: the case of Lithuania
}

\author{
Gintare Gudaityte, Vida Melninkaite, Daiva Vitkute-Adzgauskiene, and \\ Vladislav V. Fomin \\ Vytautas Magnus University, Faculty of Informatics, Kaunas, Lithuania \\ \{g.gudaityte, v.melninkaite, d.vitkute-adzgauskiene, \\ v.fomin\}@if.vdu.lt
}

\begin{abstract}
In this work we undertake an interpretative case study to analyze the periodicals market in Lithuania. Specifically, we are exploring the possible reasons for the diminishing supply of and demand for traditional print press and whether or not electronic publishing can fill in the growing gap. In this work we use data collected through Internet based survey and interviews with publishing industry players to draw conclusions on the current and future trends in the epublishing domain in Lithuania.
\end{abstract}

Keywords: publishing, electronic publishing, interpretative case study, consumer perspective, business perspective, e-Society, knowledge society.

\section{Introduction}

In 1999 Council of the European Union announced an ambitious vision of Europeans inhabiting Information Society by 2005 [5]. The vision of Information Society, dubbed as e-Europe or e-Society, was to bring forth "changes, the most significant since the Industrial Revolution" [5, p.2].

Looking at the history of national informatization processes in Europe and elsewhere one can notice that the task of building e-Society was far too often understood (or tackled) as bringing a large number of services online [6], i.e., seeing Information Society as a composite of the largest possible amount of online services.

More than a decade down the road, we have learned the hard way that the success of establishing e-Society cannot be measured by the availability of (often very complex) services provided to citizens over the Internet. The sought for transformation of society requires distribution of knowledge among the citizens and businesses to eliminate knowledge asymmetry and facilitate market and democratic processes [4].

From the viewpoint of Information Society development, the publishing industry peresents a doubly interesting object to study. First, the media as it appeared in varying forms throughout the history has always been a source of information and knowledge to people. Second, the publishing services today are being moved to the electronic (online) formats and distribution channels. Thus, electronic publishing services become a cornerstone element of economy - information is at the same time a raw material and a product [4]. 
The extent of the transformation of traditional (printed) media to electronic one is most visible in developed countries, and the US in particular. In 2010 US residents were reading more news from online sources than from printed ones; the revenues from Internet advertisements overtook those from the print media. Mobile phones became one of the primary devices to bring news to the readers [11].

The new publishing paradigm is entering Lithuania, too. Few journals and newspapers started offering their content in specially formatted online editions; electronic reader devices are being introduced to the market. However, the transformation hasn't acquired a momentum yet, the publishers are not rushing to set their foot into the new grounds - there is a lack of understanding of the business, technology, and legal aspects of the electronic publishing. There is a lack of confidence among the publishers that there is a demand for the new media, too.

The advent of electronic media in Lithuania is taking place at the time when the demand for traditional press is diminishing. Despite having the largest number of mobile phones per capita in the world, Lithuanians lag behind many of their European neighbors in affordability and literacy when it comes to the use of e-services in general and electronic media in particular.

Using interpretative case study, in this work we are trying to answer the question whether the diminishing offering of printed media is likely to be readily compensated by new electronic media services, thus preventing formation of "knowledge gap" on the way to building knowledge society in Lithuania.

\section{Research design}

In this work we use an interpretative case study method. The aim of this research work is to provide an in-depth description and interpretative analysis of processes currently taking place in the publishing domain. The case study method is particularly suitable for the aims set, as it allows recording both the process-related data and at the same time interpreting the context in which the processes unfold [15].

Our data collection strategy is based on uses of multiple sources. Academic and popular literature, structured interviews, and Internet sourvey were used to obtain different perspectives on the phenomenon under investigation. Such process of establishing counterevidence is known as triangulation and refers to verification of research findings $[2,12]$.

Literature review was conducted to obtain an overview of the (global) ongoing transforation of the media business, capture the media-related trends in consumer behavior and technology and service offering. Internet survey was used to obtain deeper understanding of the perceptions of Lithuanian consumers with regard to the electronic media. Interviews with representatives of Lithuanian publishing business helped clarify the views of the media products' and services' providers on the emerging electronic publishing paradigm.

The research was designed to cater for the following goals of the study:

- Obtain the knowledge on (possible) problems/barriers associated with the introduction of electronic publishing services in Lithuania; 
- Obtain the knowledge on the extent to which consumers accept electronic media (as an alternative to the printed one);

- Be able to juxtapose data from different sources to analyze and interpret the perspectives of electronic publishing in Lithuania.

\section{Case study: Publishing in Lithuania}

Electronic publishing has emerged as a global phenomenon. However, the lessons learned from the globalization of electronic commerce [7] suggest that (successful) business cases from e.g., US won't necessarily work in another country. Economic, legislative, cultural, and demographic difference in the context of e-service's development and/or application can render the successful service offering quite unuseful when transferred to another than the original context. Readers's preferences and expectations and publishers' innovation strategies play an important role in localization of global e-services.

Based on our expert knowledge of the general state of affairs in the e-business domain in Lithuania, we set an initial hypothesis that Lithuanian population has not yet recognized electronic publishing as a primary type of media, and that Lithuanian publishers are not (technologically) ready to stimulate the demand by increasing the epublishing product offering.

However, electronic publishing has a number of advantages over the traditional print media - hypertext, instantaneity, accessibility, among other. These advantages can stimulate the demand for the new type of media. In the following section we present a case study aimed to explore whether or not there are good prospects for the growth of demand on periodical e-publications in Lithuania.

\subsection{Transitioning from printed to electronic press}

In 2009, there were 1285 periodical titles in Lithuania: 297 newspapers, 493 magazines, 96 bulletins, 382 other kind of periodicals [9]. In 2010 the list got shorter by 28 titles. Newspapers saw the biggest impact, loosing $9 \%$ (44) of its 2009 titles or $23 \%$ (53,8 thousand) in printed coppies per annum [9]. At the same time the number of residents in Lithuania during one year decreased only by 1,6\% [13], making the relative decrease in the number of newspaper titles per capita 16. Journals titles' list got shorter by 5 , whereas the print volume decreased by $12 \%$, or 4 journals fewer per capita adjusted to the decrease in population [8]. These numbers show the downward trend in traditional (printed) media offering.

Looking at the electronic media market, there is a reverse trend - the number of registered titles has increased by 19 since 2008 to reach 259 [13].

There is also a limited number of titles, which are issued in both electronic and printed format. Three out of four most visited websites were exactly those "mixed" titles: Lrytas.lt ("Lietuvos rytas" newspaper) was \#2 receiving $42 \%$ of daily Internet users, while Balsas.lt ("Balsas" newspaper) was \#3 with $40 \%$. \#4 was 15 min.lt (" 15 min" free newspaper), which was receiving $39 \%$ of the Internet users. The most visit- 
ed website - Delfi.lt - electronic-only news portal - was receiving $55 \%$ of all Internet users in the beginning of 2011 [8].

Looking at the variety of printed press, in 2009 the most popular categories were tourism and sports (139), women and families (105), professional (76), political, philosophy, and religious (64), popular science (58), business (41), and children and youth (42).

The most popular single periodical title was "TV Antena", which is printed as a supplement to the Saturday's issue of "Lietuvos rytas" newspaper. The runnerafter was a "yellow press" magazine "Žmonès" (Lith.: "People"). The third place was held by the newspaper "Lietuvos rytas"[14].

Unlike countries like the US [11], electronic publishing in Lithuania today is a niche market. However, there are obvious signs of change - the traditional print, radio and TV media is extending its presence in the cyberspace, often through a lowerquality and free-access offerings, aiming at reaching out to a larger consumer population.

The free-access offering of the e-publishing pioneers is contributing to the formation of such consumer attitude that the freely available on the Internet e-media is dubbing the information presented in the pay-per-view or pay-for-subscription press. This means that the pioneers of e-publishing are cannibalizing on their own printed press market (if such existis) or setting consumer expectations to have free access services forever. This happened to the popular Lietuvos rytas newspaper - since the newspaper started offering a free electronic verion of the newspaper, the sales volumes for the printed newspaper fell 5\%.

Despite the seeming optimism which which Lithuanian publishers embraced the opportunities brought about by e-publishing, we are tempted to assume that the freeaccess e-publishing business can be sustained in Lithuania neither in the long, nor in the short run. These assumptions are based on the analysis of the current market trednds in Lithuania, as follows.

Since the 2008 financial crisis, revenues the publishers were earning from advertisements have fallen drastically, subscriptions to periodicals are in decline.

Several traditional journals and newspapers which started offering about or almost the same content online as in their printed press, have seen decrease in subscriptions and sales of the printed issues. A peculiar trend has emerged - the higher quality outlets, in order to keep up against the declining revenues, started offering lower quality news, which drew their traditional customers dissatisfied and eventually abandoning the outled. On the other hand, the media outlets which initially positioned themself as free-access and low quality news service see a growing demand for their offering [1].

While the service offering of electronic press market in Lithuania is very limited, the observed trends suggest there is a potential for growth. Recognizing the importance of e-services in stimulating knowledge-based economy, the state is supporting the move towards e-services with such state-funded infrastructural investment projects as e.g., the one aimed at development of innovative e-reader software and the application of it [3]. The project lasted for six months during which technical and market aspects of electronic publishing were studied. One of the conclusions the project came to was that electronic readers and paid access electronic media will become more popular when the price the consumers have to pay for the device will fall undet 250 Litas (ca. \$100). This thesis is partially supported by evidence from UK, where 
recent market research, quite contrary to the results of the early e-commerce days [7], showed the elder, not the younger part of the population are the early adopters of eservices and e-reader devices [10]. So, $6 \%$ of people in the age of over 55 were reported to be using e-readers, while only $5 \%$ in the age group of 18-24 [10].

\subsection{Survey data analisys}

The survey was conducted using an online Internet survey management tool. An invitation to participate in the survey and the actual web link (URL) to the survey were placed on the Lithuania e-survey portal apklausa.lt, as well as distributed by email to various groups and individuals. Access to the survey was open to anyone having the URL, thus making it possible to create a snowball effect in promoting the survey any one recipient of email with the URL for the survey could forward it further to anyone else. The survey was open between March and May 2011 and generated 562 responses.

The survey comprised of 18 fixed-response and open-ended questions, aimed at gathering information on citizens' preferences with regard to print and electronic media (services) consumption.

Of the total 562 respondents, 31\% were male, and 69\% were female. The largest age groups were $18-25(60 \%), 26-35$ (22\%), and $36-50(11 \%) .50 \%$ of the respondents had a university degree, $17 \%$ - special professional, and $17 \%$ - secondary education. $40 \%$ reported to have monthly income below 1000 Litas $(\$ 400), 17 \%-1000$ 1500 Litas, $13 \%-1500-2000$ Litas, and 16\% - more than 2000 Litas (\$800).

The first section of the survey dealt with the question of the frequency of and the purpose for the use of Internet. $81 \%$ of respondents are using Internet on the daily basis, while $13 \%$ - 5-6 days a week.

$92 \%$ of the respondents use the Internet to search for information, $80 \%$ - for online banking, $68 \%$ - to read newspapers and online magazines, or to download respective content. $69 \%$ use the Internet for their studies or education, while $58 \%$ - for their work. $41 \%$ use the Internet to listen to radio, watch TV. $60 \%$ - to watch/download movies or play/download games.

Answers to the questions on buying frequency and monthly budget for print media are presented in (Table 1).

Table 1. Frequency of buying the printed media and monthly spending for it

\begin{tabular}{l|l|c|c|c|c|c|c}
\hline \multirow{2}{*}{} & \multicolumn{6}{c|}{ Monthly spending on print media, Lt } & \multirow{2}{*}{} \\
\cline { 3 - 7 } \multicolumn{2}{c|}{} & 0 & 10 & $10-20$ & $20-30$ & $30+$ & Total: \\
\hline $\begin{array}{c}\text { Buying } \\
\text { frequency }\end{array}$ & Always & 1 & 14 & 35 & 13 & 20 & 82 \\
& Sometimes & 0 & 203 & 88 & 15 & 10 & 316 \\
& Never & 164 & 0 & 0 & 0 & 0 & 164 \\
\cline { 2 - 6 } & Total: & 165 & 217 & 123 & 28 & 30 & 562 \\
\hline
\end{tabular}


The results show that the majority of respondents are sometimes buying printed media products, not spending on that more than 10 Litas (\$4) per month. The second largest group is sometimes buying for the amount of 10 to 20 Litas (\$4-\$8) a month. While only 30 respondents $(5 \%)$ are ready to spend more than $30 \mathrm{Lt}(\$ 12)$ per month, and not more than $35(6 \%)$ report to always buy a print media, irrespective of their budget for it.

Answering the question, whether traditional (print) or electronic form of publications are given preference, there are about twice as many respondents giving preference to electronic media in the education categories up to the secondary education (inclusive), while for the university education the rate is more than four to 1. Overall, only 125 respondents $(22 \%)$ prefer printed media to electronic one.

When asked whether they feel a need to use electronic publishing products, $73 \%$ of respondents answered "yes".

When looking at the frequency and duration of reading from electronic sources, the distribution of responses appears to be quite even across the categories (see Table 2).

Table 2. Frequency and duration of reading of electronic media sources

\begin{tabular}{|c|c|c|c|c|c|c|c|}
\hline & \multicolumn{5}{|c|}{$\begin{array}{l}\text { Average time of reading } \\
\text { (for each access event) }\end{array}$} & \multirow[b]{2}{*}{ Total: } \\
\hline & & $<15 \mathrm{~min}$ & $\begin{array}{l}15-30 \\
\min \end{array}$ & $\begin{array}{l}30-60 \\
\min \end{array}$ & $>60 \mathrm{~min}$ & $0 \mathrm{~min}$ & \\
\hline \multirow{6}{*}{ 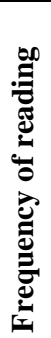 } & Few times a day & 11 & 55 & 65 & 18 & 0 & 149 \\
\hline & Once a day & 10 & 85 & 54 & 6 & 0 & 155 \\
\hline & Weekdays only & 3 & 17 & 16 & 3 & 0 & 39 \\
\hline & $\begin{array}{l}\text { 2-3 times a } \\
\text { week }\end{array}$ & 47 & 67 & 93 & 12 & 0 & 219 \\
\hline & don't read & 0 & 0 & 0 & 0 & 0 & 0 \\
\hline & Total: & 71 & 234 & 218 & 39 & 0 & 562 \\
\hline
\end{tabular}

At least once a day electronic media is reported to be read by 304 (54\%) respondents, most of them reading for 15 to 60 min each time.

Another section of the survey deals with the types of electronic periodicals. $27 \%$ of respondents read online/electronic magazines and 25\% - newspapers or news. Other popular types of media are dictionaries, vocabularies, encyclopedia $(20 \%$ of respondents). Only $1 \%$ of respondents reported not to be interested in any kind of elelctronic media.

To find out what qualities of electronic media are the most valued by the reader, questions were asking on the content of electronic publications. Among the most important characteristics for electronic media respondents name trustworthyness of information (74\%) and (relevant) content (71\%). The following in the importance characteristic is the non-sophisticated presentation of the information $(39 \%)$. This includes easy access and intuitive layout of the electronic publication. 
Interactivity is ranked almost evenly as important (39\%) and not so important (35\%). This may suggest that the readers are not used to (highly) interactive design, preferring simplicity of presentation to that of reachness of features.

Peculiarly, for the majority of respondents, violation of copyright is not an important issue - only $40 \%$ rated this factor as important or very important, while $26 \%$ as non-important, or totally unimportant.

The price of electronic press in Lithuania is currently set at about the same level as for similar printed editions. Therefore, it was asked in the survey whether respondents would be willing to buy electronic media if its price was considerably lower than that of the print press. The answers received show that Lithuania readers aren't ready to pay for electronic media $-45 \%$ of respondents aren't sure they need electronic publications at all. $29 \%$ would have bought electronic publications if these were cheaper than the printed ones, while the choice being constrained by multiple other factors, such as the publication type/subject, its accessibility and the price.

Another important question relates to the availability and popularity of e-reader devices. $78 \%$ of respondents have heard about (the existence) of e-reader deveices, while $17 \%$ - haven't. Only $5 \%$ reported to have one.

When asked, what could stimulate their interest towards electronic press, the majority wished to have a wider choice of electronic media (27\%) and lower prices for it (26\%). $23 \%$ wished to have a wider range of and a lower price for e-reader devices, while $11 \%$ wished the digital rights management and copy-protection systems weren't as stringent.

When asked whether they see the electronic press as having advantage over the printed one, $28 \%$ gave positive answers and $27 \%$ - negative. The remaining $45 \%$ saw the two forms of publishing as equal.

\subsection{Summary on the data analysis}

The survey data analysis shows that the Internet usage in Lithuania is high, people use the Internet to search for information, use e-banking services, read newspapers and magazines. There is a diminishing demand for traditional print media, as users are not willing to spend more than 10 Litas $(\$ 4)$ per month on printed periodicals. At the same time, the need for electronic media is high.

Most read categotries of electronic periodicals are magazines and newspapers. For reading electronic media, people allocate a substantial portion of their time on a daily basis. When choosing what to read (online), respondents give preference to the quality and content of information source. Whether or not the information is obtained lawfully is of little concern to Lithuanian reader.

The use of e-readers is deminitive, although the majority of the readers are aware that such devices exist. Lower price for e-reader, lower access fee for electronic media, and wider choice of electronic publications - these are named as factors that will stimulate the growth of e-publishing services. At the same time, respondents evaluate the importance of electronic and print press as equal. 


\section{Conclusions}

Having conducted case study and data analysis, we can conclude that Lithuania, similar to many other countries, currently transitions from printed press market to electronic one. On the backdrop of decreasing demand for traditional media, Lithuanian publishers are likely in the short run to face two alternatives - shift to electronic press or close their business all together.

The concept of electronic publishing is often compared to that of the traditional one. Features and business models, that are typical to traditional media pertain to electronic media, too. Therefore, many drivers and barriers which can be found in traditional press business are relavant for the electronic press. In one possible setup, electronic periodical can be simply mirroring a printed publication, where the content of the printed document, page layout, etc. are replicated. In another setup, electronic periodical can exist without its printed twin.

The interview data analysis allowed us to assume that publishers in Lithuania are sceptical about the business prospects of electronic publishing. At the same time, they understand that new technologies are advancing rapidly and changes in the publishing domain are inevitable. Small market size, plagiarism, lack of legal basis, lack of initiatives and creativity are named as the biggest barriers for publishers in deciding to transition to electronic press. A conclusion can be drawn, that the main issue for owners of electronic publishing in Lithuania is the lack of (knowledge on) sustainable business strategies and transition models. Also, the supply of e-reader devices is currently too low, and their price is too high. Additional technical issue to consider is the lack of knowledge on feasible solutions for content safety and format compatibility.

Our conclusions are supported by the fact, that the absolute majority of electronic versions of Lithuanian periodicals is implemented in a form of an online hypertext twin of the printed version. Such setup is limiting business possibilities of the publishers due to commonly reported unwillingness of Lithuanian internet users to pay for information access services. Commercial ads in this case won't lead to a sustainable business model due to overly small market segments for most periodicals.

\section{$5 \quad$ Managerial implications}

Finalizing, we can draw few managerial implications for the e-publishing business:

- The uptake of e-publishing in Lithuania can be stimulated by introducing e-reader devices and developing e-reader versions of periodicals. Use of e-reader for distributing electronic versions of periodicals would allow to use business models similar to the ones used for traditional print media, thus reducing the economic risk in the context of overly small publishing markets.

- The use of e-readers for the distribution of electronic press would limit the uncertainties the publishers are facing with regard to unauthorized (re-)distribution of media by users/customers. The hardware-based media distribution approach would provide the copyright owners with better possibilities and tools for copy-, redistribution- and access control. 
- Building on the experience of successful business model of mobile phone subsidization by mobile operators, publishers of electronic media could offer a possibility to purchase e-reader devices at a lower price, given that consumers subscribe to receive paid electronic publications for a certain period of time.

- Traditional press publishers are encouraged to publish on the Internet, at the same time, as electronic publications serve as advertisement for the printed one. Presence in the electronic domain also creates possibilities for establishing feedback sites with readers. However, e-reader version should be considered in addition to the online version.

- Owners of existing and future electronic periodicals should be very careful in selecting (publication) standards in order to attract larger audience at the backdrop of the existing diversity of e-reader devices. Following common European and Lithuanian information infrastructure development frameworks, we recommend to use .pdf and .epub formats for electronic periodicals, as these are based on open standards and thus can support larger variety of devices.

- The use of open standards is recommended, their advantage being in the ease of access of corresponding electronic publications. This results in the increase in freedom of choice for the end user, avoiding the promotion of one single producer.

\section{References}

1. 15min.lt, Trečdaliu auga „15 min“ tiražas (The circulation of "15 min" grows by one third). 15. 2011, 15min.lt: Kaunas.

2. $\quad$ G.R. Adams and J.D. Schvaneveldt, Understanding Research Methods, Second ed., N.Y.: Longman Publishing Group, 1991.

3. Agmis.lt, Agmis pasirašè sutartị dèl ES iš dalies finansuojamų elektroninio formato leidinių mokslinių tyrimų (Agmis signed agreement on scientif research reagrding partial ES financing for electronic format publications). 2010, Vilnius.

4. M. Castells, The Rise of the Network Society, 2nd (2000) ed., The Information Age: Economy, Society and Culture, Vol. I, Oxford: Blackwell Publishers, Ltd, 1996.

5. Council of the European Union, eEurope. An Information Society for All. 1999.

6. E.M. Daniel and H.N. Wilson, "Dynamic capabilities in e-business transformation," European Journal of Information Systems, vol. 12, 2003, pp. 282-296.

7. V.V. Fomin, J.L. King, K. Lyytinen, and S. McGann, "Globalization and E-Commerce VII: Environment and Policy in the U.S.," Communications of the Association for Information Systems (CAIS), vol. 10, no. Article 8, 2003, pp. 276-325.

8. gemiusAudience, gemiusAudience: The most reliable source of knowledge about the Internet and its users. 2010, www.audience.lt.

9. Lietuvos Nacionaline Biblioteka, Lietuvos spaudos statistika $2009 \mathrm{~m}$. (Lithuanian National Library, Statistics of Lithuanian Press in 2009), Lietuvos nacionalinè Martyno Mažvydo biblioteka (Lithuanian National Martynas Mazvydas Library), 2010.

10. Redsauce.com, E-book popularity set to increase this year. 2011, Redsauce.com.

11. T. Rosenstiel and A. Mitchell, The state of the New Media 2011. An annual Report on American Journalism. 2011, http://stateofthemedia.org/.

12. R.E. Stake, "Case studies," in Norman K. Denzin and Yvonna S. Lincoln, ed., Handbook of Qualitative Research, Thousand Oaks: Sage Publications, 1994, pp. 236-247.

13. Statistics Lithuania, Statistical Yearbook of Lithuania 2010, Statistikos departamentas (Department of Statistics), 2010. 
14. TNS.lt, Baltijos šalių leidinių skaitomumas 2010 ruduo (Readability of Baltic country publications, Autumn 2010). 2011, Vilnius.

15. R.K. Yin, Case Study Research. Design and Methods, Second ed., Thousand Oaks, London, New Delhi: Sage Publications, Inc., 1994. 